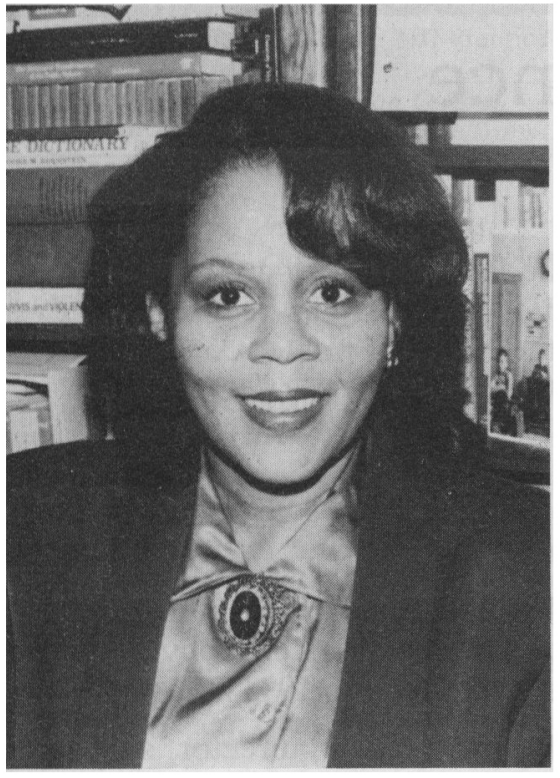

Paula D. McClain

Paula D. McClain, chair, Woodrow Wilson Department of Government and Foreign Affairs, University of Virginia, effective July 1, 1994.

\section{New Appointments}

Christopher Anderson, assistant professor, department of political science, Rice University; formerly Washington University in St. Louis.

Earl Black, Herbert S. Autrey Professor of Political Science, Rice University; formerly University of South Carolina.

Carolyn Funk, assistant professor, department of political science, Rice University; formerly University of California, Los Angeles.

Dean C. Hammer, assistant professor of political theory, department of government, Franklin and Marshall College.

E. Brooke Harlowe, assistant professor and coordinator of international studies, department of political science, Susquehanna University.

Wolfgang Hirczy, assistant professor, department of political science, Oklahoma State University, formerly University of Houston.
Kevin P. Lane, assistant professor of comparative government, department of government, Franklin and Marshall College.

Thomas Longoria, Jr., assistant professor of political science, University of Wisconsin-Milwaukee; formerly Texas A\&M University.

Matthew M. Schousen, instructor of American government, department of government, Franklin and Marshall College.

\section{Promotions}

Michael Brecher, Department of Political Science, McGill University, named R.B. Angus Professor of Economics and Political Science.

Gavan Duffy, assistant professor with tenure, department of political science, Syracuse University.

Thoms M. Holbrook, associate professor of political science with tenure, University of WisconsinMilwaukee.

Rosemary O'Leary, associate professor with tenure, department of public administration, Maxwell School of Citizenship and Public Affairs, Syracuse University.

Carol Swain, associate professor of politics and public affairs, Woodrow Wilson School of Public and International Affairs at Princeton University.

\section{Visiting and Temporary Appointments}

Barry Bozeman, director, Center for Technology and Information Policy, Maxwell School, Syracuse University, visiting professor of public policy at the Institute for Public Policy Studies, University of Michigan, 1993-1994.

Susan E. Clarke, University of Colorado at Boulder, Visiting Fellow, Government Department, University of Essex, 1993-94.

B. J. Moore, visiting instructor, department of political science and public administration, University of Toledo.

\section{Award Recipients}

\section{Catt Center Prize Winners Named}

The Carrie Chapman Catt Center for Women and Politics of the Iowa State University has named the winners of the first Carrie Chapman Catt Prizes for Research on Women and Politics. Robin M. Le Blanc of the Carl Albert Center, University of Oklahoma was awarded the $\$ 1000$ Graduate Student Prize for her work, "Homeless as Citizens: The Political World of the Japanese Housewife." Pauline E. Schloesser of Indiana University was chosen as runnerup. Leonie Huddy, SUNY Stony Brook, was awarded the Faculty Prize of $\$ 1000$ for her essay "Feminism and Feminists: A Symbolic Politics Study.' Faculty Prize runner-ups include Nancie Caraway, Georgetown University; Nancy J. Hirshman, Cornell University; and Lyn Kathlene, Purdue University. The two winners and the runnerups were invited to participate in the Prize Colloquium held on March 4 in Ames, Iowa.

\section{NYSPSA Announces Awards}

The New York State Political Science Association has named award winners for the best papers presented at the NYSPSA 1993 Annual Meeting.

The award for the best paper by a graduate student was presented to Miriam Fendius of the department of political science, Columbia University for her paper titled "The Foreign Policies of Small States: Challenging Neutralism on its Own Home Court.",

The award for the best paper by a practicing political scientist was shared by two authors: Mark Maier of the school of education and human development, Binghamton University of the State University of New York for his paper "The Challenger Disaster: Routine Processes, Disastrous Consequences," and Robert W. Bailey of the school of international and public affairs, Columbia University for his paper "Neo-Institutionalism and the Allo- 
cation of Debt Capacity in New York: A Case of Institutional Transformation."

\section{Other Awards}

Lucius J. Barker, William Bennett Munro Professor, Stanford University, was the recipient of the University of Illinois 1993 Alumni Achievement Award.

Paul F. Diehl, associate professor of political science, University of Illinois at Urbana-Champaign, has been named a 1993 University Scholar.

Betty Glad, department of government and international studies, University of South Carolina, has been named a Carolina Research Professor.

Thomas Heilke, department of political science, University of Kansas, has been awarded a Research Fellowship by the Pew Evangelical Scholars Program for academic year 1994-95.

Kathleen Hall Jamieson and Joseph

N. Cappella of the Annenberg School for Communication at the University of Pennsylvania received a $\$ 708,500$ grant from the Robert Wood Johnson Foundation to study the ways in which the press covers and the public learns about health care policy.

David Kirkwood Hart, the J. Fish Smith Professor of Free Enterprise Studies, in the Institute of Public Management, Brigham Young University, was named the 1993 Distinguished Alumnus of the Claremont Graduate School. Earlier, he received the 1993 Outstanding Professor Award from the Marriott School of Management at Brigham Young University.

Evelyne Huber and John D. Stephens, department of political science, University of North Carolina at Chapel Hill, were co-winners of the Outstanding Book Award 1991-1992 from the American Sociological Association, Political Sociology Section, for Capitalist Development and Democracy (coauthored with Dietrich Rueschemeyer, Brown University), published by the University of Chicago Press and Polity Press, 1992.

Ellen Mickiewicz, professor of public policy and political science, Duke University, was honored by the Journalists Union of Russia for her work with the Commission on Radio and Television Policy. The Commission was founded by former president, Jimmy Carter, to encourage the use of the media to enhance democracy.

William D. Pederson, Louisiana State University-Shreveport, was presented with the annual Achievement Award by the Abraham Lincoln Association in recognition of his role in organizing the first Lincoln conference in the Deep South and directing the first summer institute on Lincoln in the nation for secondary teachers.

Susan Scarrow, University of Houston, was the winner of the 1993 Samuel H. Beer Dissertation Prize given by the British Politics Group at the APSA Annual Meeting. The dissertation, titled "Organizing for Victory: Political Party Members and Party Organizing Strategies in Great Britain, 1945-1989," was written under the direction of David Cameron at Yale University.

Joan Edelman Spero, formerly of Columbia University and currently

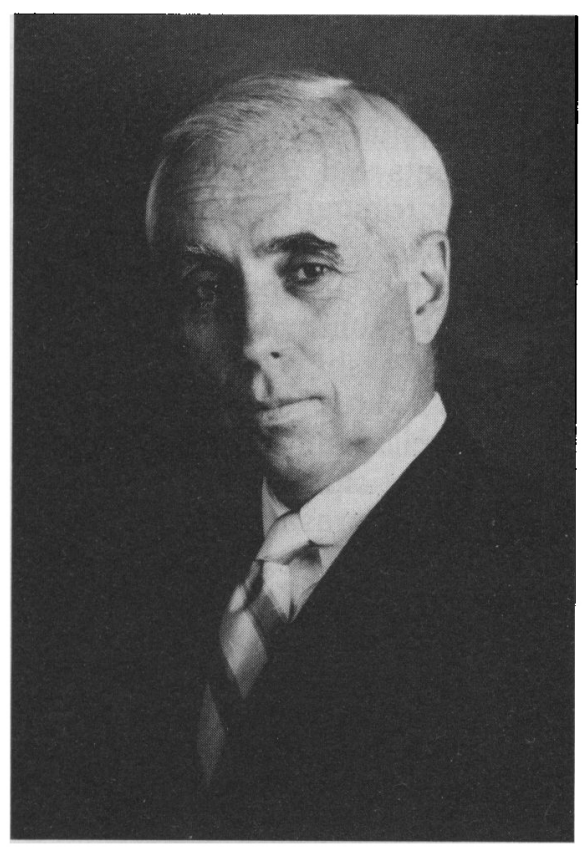

David Kirkwood Hart
Undersecretary of State for Economic and Agricultural Affairs, was named the George Washington University Distinguished Statesperson of the Year.

Carol Swain, associate professor of politics and public affairs, Woodrow Wilson School of Public and International Affairs, Princeton University, was the recipient of a Young Investigator Award from the National Science Foundation. Swain is spending this academic year as a Russell Sage Foundation Visiting Scholar conducting research on the effect of information on white voters' evaluation of black congressional candidates.

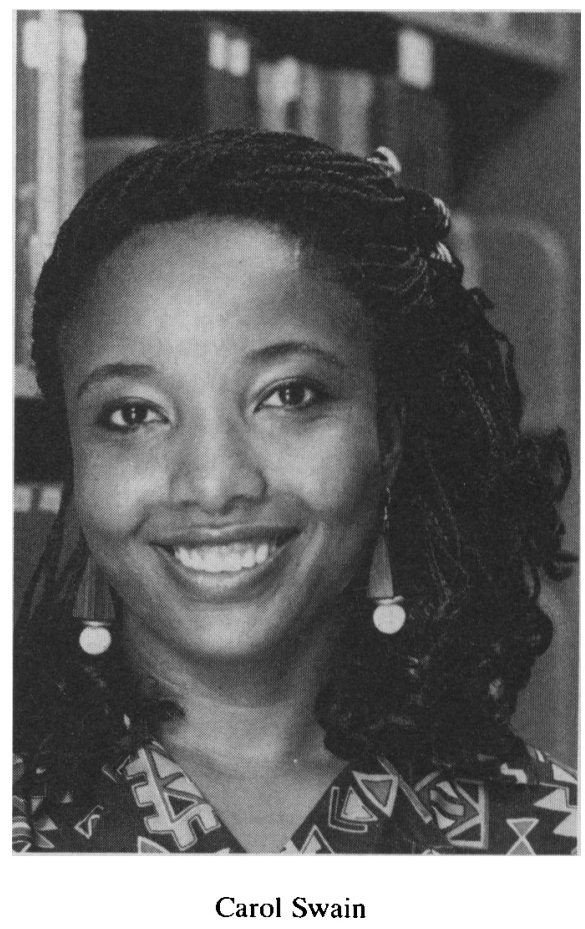

Marvin G. Weinbaum, professor of political science, University of Illinois at Urbana Champaign, has received the Harriet and Charles Luckman Undergraduate Distinguished Teaching Award.

Susan Welch, Dean, College of Liberal Arts and professor of political science, Pennsylvania State University was the recipient of the University of Illinois 1993 Alumni Achievement Award.

Frederick M. Wirt, department of political science, University of Illinois at Urbana-Champaign, has been named winner of the first 
Lifetime Achievement Award by the Politics of Education Association (PEA). The award, which recognizes Wirt's scholarly contributions to the field of politics of education, will be presented this April as part of PEA's 25th anniversary celebration.

Dina A. Zinnes, professor of political science, University of Illinois at Urbana-Champaign, was the recipient of the 1994 APSA Career Achievement Award, Conflict Processes Section.

\section{In Memoriam}

\section{Hugh A. Bone}

For the last half century, Hugh A. Bone guided students through the halls of learning not only at the University of Washington but also in the state capitol. After retiring from teaching in 1979 at the age of 70 , he was invited back to direct interns and share his wisdom about Washington State politics with colleagues and students. He remained an active member of the university community until his recent death on February 5, 1994.

In 1956, Hugh Bone pioneered the Washington State Legislative Internship Program. Since then, the Olympia program has become a national model, and now includes participants from the state's other four-year colleges and universities. In keeping his lifelong commitment to teach students about the political process through firsthand experience in government, Professor Bone supervised many generations of UW interns working for state lawmakers during their annual session. Over the years, countless students have been motivated by Bone to take an active part in public affairs, and many have gone on to occupy public office.

When Bone "officially" retired from the political science faculty in 1979 , both the State Senate and the House of Representatives passed resolutions recognizing his contribution to citizen education. Valued for his expertise and counsel, the legislators warmly addressed Bone as "friend, adviser, and teacher."
Bone's dedication to teaching responsible citizenship surfaced early in his career. In 1935, he completed his master's degree at the University of Wisconsin with a thesis entitled "Civic Education in Political Science." Then he took his Ph.D. at Northwestern University where he wrote his dissertation, "The Effects of College Teaching on Student Political Attitudes and Interests."' He joined the University of Washington faculty in 1948 to teach American government and politics, including specialized courses in political parties, state legislatures, the U.S. Congress, and state government. $\mathrm{He}$ also served as chairman of the Department of Political Science for a decade, from 1959 to 1968 , and was president of the Western Political Science Association.

As a scholar in American government, Bone published twelve books, including American Politics and the Party System, Politics and Voters, and Washington Politics, as well as numerous articles on state and national politics. As an advocate of political participation, Bone was appointed to serve on committees by the governor, the mayor of Seattle, the secretary of state, and the legislature, and worked as a consultant to diverse civic groups and organizations.

In the words of a former student, Bone's enduring contribution to the community is "his ability to inspire active, responsible citizenship in his students and associates."

To pay tribute to Professor Bone for his achievements in advancing public service, friends and former students established the Hugh A. Bone Scholarship in 1986. The fund provides awards to financially needy, well-qualified undergraduates for participation in a full-time legislative internship program sponsored by the Department of Political Science. Contributions can be sent to: The Hugh A. Bone Scholarship, c/o Alumni/Donor Information Systems, 4534 11th Ave., N.E., 2nd Floor, Seattle, WA 98105.

Robert J. Sickels

University of Washington

\section{Dorothy I. Cline}

Dorothy I. Cline, professor emerita at the University of New Mexico, died at her home in Albuquerque on December 4, 1993, at the age of 89 . She was born in Michigan, worked for Harry Hopkins during the New Deal, and earned a bachelor's degree at the University of Michigan and a master's in political science at the University of Chicago. She remained, accordingly, active in both civic and academic affairs throughout her long life.

In 1936, she served as training director in the Recreation Division of the Works Progress Administration and later as a community analyst for the Office of Civil Defense. In New Mexico, along with her teaching and writing, she was chair of the Bernalillo County Commission, organizer and chair of the New Mexico Commission on the Status of Women, vice president of the New Mexico Constitutional Convention, and director of health and recreation in the State Department of Education, and in 1967 she was appointed by President Johnson to the National Advisory Commission on Intergovernmental Relations. At the university, Professor Cline was director of the Division of Government Research. After her retirement she received the New Mexico Distinguished Public Service Award.

In 1946 she became the first woman in the Department of Government, as it was then known, and helped change its name to Government and Citizenship. (Later, certainly without her encouragement, it became more austerely the Department of Political Science.) Among her later publications were an essay on "Constitutional Politics in New Mexico: 1910-1976”' in New Mexico Government (1976), New Mexico's 1910 Constitution (1985), and Reorganization of the Executive Branch of State Government (1978). She retired in 1970 and remained active to the end. She will be remembered as a person of extraordinary drive, courage, and candor.

Mary F. Boughton

University of New Mexico 